\section{Cranial cavity filled with cerebrospinal fluid in an otter (Lontra longicaudis) - case report}

[Cavitação craniana preenchida por fluido cerebroespinhal em lontra (Lontra longicaudis) - relato de caso]

\author{
L.V.L. Costa ${ }^{1}$, M.A. Bonelli ${ }^{1}$, I.C.C. Silva ${ }^{1}$, M.S. Santos ${ }^{2}$, \\ T.H.T. Fernandes ${ }^{3}$, T. Schwarz ${ }^{4}$, F.S. Costa ${ }^{1 *}$ \\ ${ }^{1}$ Universidade Federal Rural de Pernambuco - Recife, PE \\ ${ }^{2}$ Zoológico Parque Dois Irmãos - Recife, PE \\ ${ }^{3}$ Centro Universitário Maurício de Nassau - Recife, PE \\ ${ }^{4}$ University of Edinburgh - Edinburgh, Scotland
}

T.H.T. Fernandes

https://orcid.org/0000-0002-8766-2271 T. Schwarz

https://orcid.org/0000-0001-8412-573X F.S. Costa

https://orcid.org/0000-0003-2763-4348

\begin{abstract}
Computed tomography of the head of an otter with a history of incoordination, visual deficits, and seizures was performed. Intracranial images revealed a large non-enhancing fluid attenuating cystic lesion in the left frontoparietal region communicating with the left lateral ventricle and subarachnoid space. These findings are consistent with a congenital brain cavity filled by cerebrospinal fluid, with porencephaly being the most probable diagnosis based on the clinical and tomographic findings. The authors highlight the rarity of such a cystic lesion in wild animals, with this being the first report in otters.
\end{abstract}

Keywords: central nervous system, poroencephaly, computed tomography, congenital disorder, wild animals

\title{
RESUMO
}

Realizou-se o exame tomográfico do crânio de uma lontra com histórico de incoordenação, déficit visual e convulsões. Imagens intracranianas revelaram grande lesão cística não captante de contraste em região frontoparietal esquerda, apresentando comunicação com o ventrículo lateral esquerdo e espaço subaracnoidea. Esses achados foram consistentes com cavitação cerebral congênita preenchida por fluido cerebroespinhal, sendo porencefalia o diagnóstico de maior probabilidade com base nos achados clínicos e tomográficos. Destaca-se a raridade dessa condição em animais silvestres, sendo este o primeiro relato em lontras.

Palavras-chave: sistema nervoso central, porencefalia, tomografia computadorizada, desordem congênita, animais selvagens

\section{INTRODUCTION}

Cystic intracranial malformations filled with cerebrospinal fluid (CSF) are occasionally reported in domestic animals and should be considered as a possible cause of seizures, blindness, ataxia, and other neurologic issues (Lee et al., 2009; Mackillop, 2011; Davies et al., 2012; Machado, 2012; Schmidt et al., 2012; Hori et al., 2015). Similar conditions are rarely

Recebido em 14 de agosto de 2018

Aceito em 16 de abril de 2019

*Autor para correspondência (corresponding author)

E-mail: fabianosellos@hotmail.com described in wild animals, but there are reports of cerebral malformation with similar macroscopic characteristics in primates (Hirowatari et al., 2012) and a fennec fox (Yamazaki et al., 2016). Generally, cerebral malformations such as these are considered secondary to environmental factors, such as toxins or infections and vascular changes during the fetal period resulting in compromised brain perfusion and cortical tissue development (Greene et al., 1982; Sharp et al., 1999; Lee et al., 2009; Mackillop, 2011; Davies et al., 2012; 
Machado, 2012; Schmidt et al., 2012; Hori et al., 2015).

Diagnostic imaging is very important for diagnosing several diseases in wild animals since, in these cases, information obtained from history and general clinical examination are usually limited (Cubas et al, 2014). Advanced imaging techniques, namely computed tomography (CT) and magnetic resonance (MRI), are helpful for diagnosing intracranial malformations (Davies et al., 2012; Schmidt et al., 2012; Hori et al., 2015). However, to the authors knowledge, there are few descriptions of the imaging characteristics of cystic lesions with fluid compatible with CSF in domestic animals and none in wild animals. The objective of this paper was to report the case of a CSF-filled cystic lesion in an otter, focusing on the clinical and tomographic aspects, as well as discussing the main differential diagnoses.

\section{CASUISTRY}

An otter (Lontra longicaudis), female, with an estimated 2 months of age, was found in the woods after its mother was killed by hunters near the metropolitan region of Recife, Pernambuco, Brazil. It was sent to the Center of Triage for Wild Animals (CETAS - Tangara). An initial clinical evaluation showed a stable condition and the otter was placed under observation for later reintroduction into the wild. After one month in captivity, the otter showed progressive signs of incoordination, visual deficit, and seizures. Hematology revealed macrocytic hypochromic anemia, hyperproteinemia, leukocytosis, and thrombocytosis. Biochemical analyses showed elevated ALT, AST, and urea with normal levels of creatinine. Based on clinical signs and laboratory results, an intracranial lesion was suspected. Computed tomography of the head was performed at a veterinary diagnostic imaging center.

The otter was placed under general anesthesia for the computed tomography scan. Anesthetic premedication was done with intramuscular dexmedetomidine (Dexdomitor ${ }^{\circledR}$ ) at a dose of $0.002 \mathrm{mg} / \mathrm{kg}$, followed by anesthetic induction and maintenance with isoflurane diluted in 100\% oxygen. For the CT scans, a helical CT scanner GE HiSpeed FXI $^{\circledR}$ was used. Scanning protocol included $120 \mathrm{kVp}$ and auto $\mathrm{mA}$ at a speed of one rotation per second, and pitch of 1 . Images were acquired craniocaudally as 1-mm transverse slices using soft tissue and bone filters. After the scan, an $\alpha 2$ - adrenergic antagonist, atipamezole at a dose of $0.002 \mathrm{mg} / \mathrm{kg}$ (Antisedan ${ }^{\circledR}$ ) was administered intramuscularly.

Transverse images were obtained before and after intravenous administration of iodinated contrast agent (Optiray® 87 350). The images were reviewed by three authors, including a Board-Certified Radiologist, using DICOM viewing software (Horos, Purview, Annapolis MD, USA, version 90 1.1.7). The osseous structures of the skull were symmetric and fontanelles and sutures were seen to be closed on three-dimensional reconstruction (Figure 1). Precontrast CT images revealed a hypoattenuating area of cystic appearance located in the left frontoparietal region. The contents of the cystlike structure had an attenuating degree of 4 Hounsfield units (HU), which is similar to the radiographic attenuation of cerebrospinal fluid. The lesion had approximately $2.23 \mathrm{~cm}$ in length, $1.12 \mathrm{~cm}$ in width, and $1.65 \mathrm{~cm}$ in height (Figure 2 A-E). There was communication with the subarachnoid space and with the ventricular system, but there was no mass effect (Figure 2 D-E). There was no enhancement after administration of the contrast. The adjacent brain parenchyma had normal radiographic attenuation. There were no signs of an associated neoplastic, inflammatory, or infectious process. The right and left lateral ventricles were asymmetric, with the left lateral ventricle larger than the right (Figure $2 \mathrm{D}$-E). There was a midline shift to the left resulting from the absence of brain parenchyma and consequent accommodation of the contralateral parenchyma. 


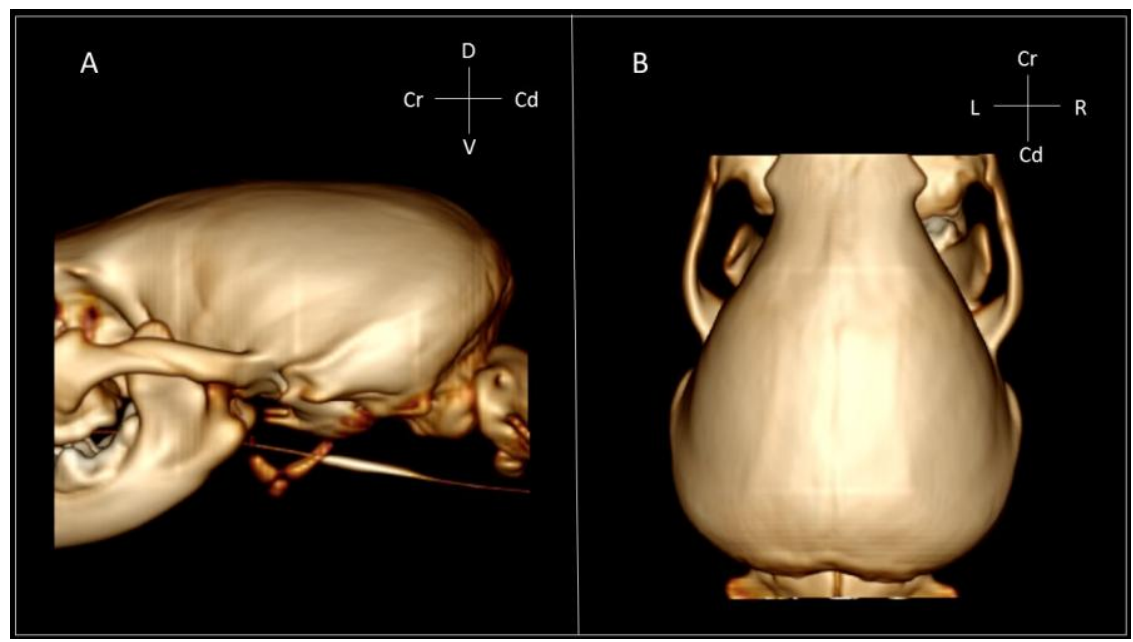

Figure 1. Left lateral (A) and dorsal (B) three-dimensional reconstruction images of the skull of an otter with brain cavitation filled with cerebrospinal fluid. Note the integrity of the bony structures and closed fontanelles and cranial sutures.

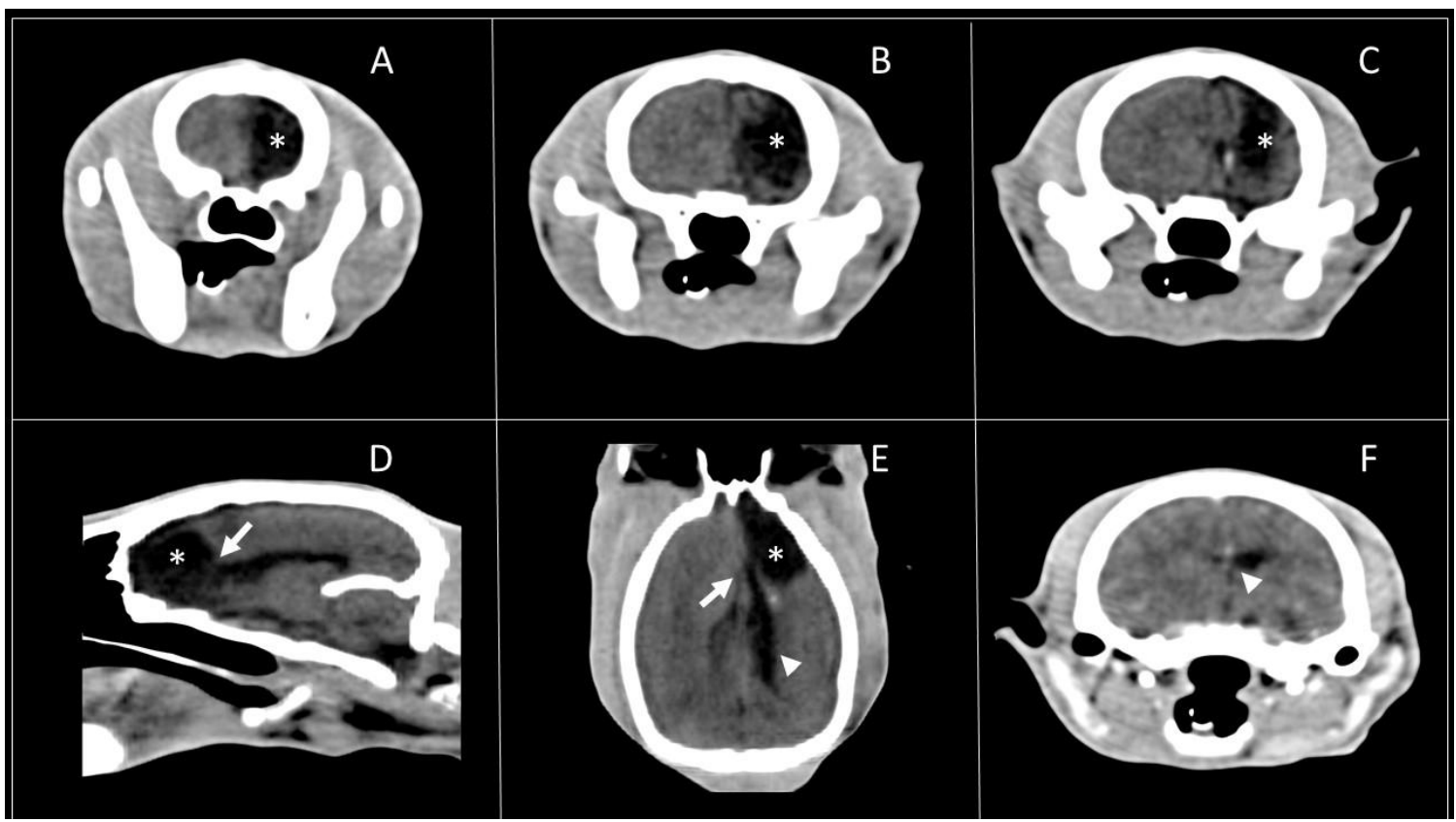

Figure 2. Transverse (A-C) and multiplanar sagittal (D) and dorsal (E) reconstruction tomographic images of the skull of an otter showing brain cavitation filled with cerebrospinal fluid (*). Note the communication with the left lateral ventricle (D-E, arrows) and dilation of the left lateral ventricle when compared to the right ventricle (E-F, arrowheads).

Imaging findings were intracranial cystic cavitation filled with fluid consistent with CSF, likely due to cerebral malformation whose main differentials would be porencephaly and hydranencephaly. Symptomatic treatment was implemented, however, there was progressive worsening over the following two weeks and the otter developed lack of appetite, diarrhea, and weakness. The otter did not improve and died 30 days after initial clinical signs. A necropsy was not authorized by the organizations responsible for the animal, so direct macroscopic or histopathological analyses of the brain were not performed. 


\section{DISCUSSION AND CONCLUSIONS}

Computed tomographic findings in this case indicated a fluid filled cystic distension of the subarachnoid space and concurrent brain atrophy. This is compatible with a cerebral malformation, and the main differentials would be porencephaly and hydranencephaly (Lee et al., 2009). Porencephaly is suggested as the most likely diagnosis in this case. Porencephaly usually presents as an area of cavitation with fluid content within the brain parenchyma which may or may not be connected to the ventricular system and subarachnoid space. Hydranencephaly is a more severe form, characterized by absence of the cerebral hemisphere, with the resulting space filled with cerebrospinal fluid within a normal-sized skull (Schmidt et al., 2012).

Clinical signs in animals with porencephaly may be absent at birth and develop after several years (Machado, 2012). Reported clinical signs include seizures, pleurothotonus, and behaviour changes, such as aggressiveness (Cubas et al., 2014). In humans, main clinical signs include seizures, which are usually refractory to treatment, spastic paresis, and delayed cognitive development (Pokhraj et al., 2014). There is a report where a diagnosis of porencephaly was obtained based on tomographic findings in a new-born human patient (Pokhraj et al., 2014); however, most authors highlight the importance of macroscopic and histopathological analyses to better categorize the lesion and establish a definitive diagnosis (Hirowatari et al., 2012; Yamazaki et al., 2016). Magnetic resonance imaging is also indicated in these cases, and is considered the method of choice for detection of intracranial lesions (Mackillop, 2011; Schmidt et al., 2012; Hori et al., 2015). Unfortunately, an MRI examination was not available in this case.

In humans, these types of cystic lesions are often severe and carry a poor prognosis, with most patients dying within a few weeks or months (Pokhraj et al., 2014). In companion animals, the evolution of these types of cystic lesions is variable. It may result in death or be an incidental imaging finding (Sharp et al., 1999). To the authors' knowledge, this is the first reported case of a cystic lesion in the brain parenchyma in an otter. It is also believed to be the first computed tomography description of these findings in a wild animal.

\section{REFERENCES}

CUBAS, Z.S.; SILVA, J.C.R.; CATÃO-DIAS, J.L. Tratado de animais selvagens: medicina veterinária. 2.ed. São Paulo: Roca, 2014. 2512p.

DAVIES, E.S.S.; VOLK, H.A.; BEHR, S. et al. Porencephaly and hydranencephaly in six dogs. Vet. Rec., v.170, p.179, 2012.

GREENE, C.E.; GORGASZ, E.J.; MARTIN, C.L. Hydranencephaly associated with feline panleukopenia. J. Am. Vet. Med. Assoc., v.180, p.767-768, 1982.

HIROWATARI, C.; KODAMA, R.; SASAKI, Y. et al. Porencephaly in a cynomolgus monkey (Macaca fascicularis). J. Toxicol. Pathol., v.25, p.45-49, 2012.

HORI, A.; HANAZONO, K.; MIYOSHI, K. et al. Porencephaly in dogs and cats: relationships between magnetic resonance imaging (MRI) features and hippocampal atrophy. J. Vet. Med. Sci., v.77, p.889-892, 2015.

LEE, K. J.; YAMADA, K.; TSUNEDA, R. et al. Imaging diagnosis-porencephaly in a calf. Vet. Radiol. Ultrasound, v.50, p.301-303, 2009.

MACHADO, G.F. Porencephaly and cortical dysplasia as cause of seizures in a dog. BMC Vet. Res., v.8, p.1-6, 2012.

MACKILLOP, E. Magnetic resonance imaging of intracranial malformations in dogs and cats. Vet. Radiol. Ultrasound, v.52, p.42-51, 2011.

POKHRAJ, P.S.; JIGAR, P.J.; CHETAN, P. et al. Congenital porencephaly in a new born child. $J$. Clin.. Diagn Res., v.8, p.1-2, 2014.

SCHMIDT, M.J.; KLUMPP, S.; AMORT, K. et al. Porencephaly in dogs and cats: magnetic resonance imaging findings and clinical signs. Vet. Radiol. Ultrasound, v.53, p.142-149, 2012.

SHARP, N.J.; DAVIS, B.J.; GUY, J.S. et al. Hydranencephaly and cerebellar hypoplasia in two kittens attributed to intrauterine parvovirus infection. J. Comp. Pathol., v.121, p.39-53, 1999.

YAMAZAKI, M.; YOSHIMOTO, S.; ISHIKAWA, T. et al. Porencephaly in a fennec fox (Vulpes zerda). J. Vet. Med. Sci., v.78, p.1749-1751, 2016. 